\title{
Building with Nature in landscape practice
}

\section{Maike van Stiphout}

DS landscape architects, Amsterdam, The Netherlands 


\section{Abstract}

In a world where increased prosperity has created a number of novel, ecosystem-related threats to people's health and the economy, designing with nature offers a promising outlook to mute the potential negative impacts of our actions and to keep improving the quality of life worldwide. It also provides an alternative to an attitude that has been largely negligent towards our nonhuman fellow beings.

Drawing from the experience of DS landscape architects, four actualized projects and two student master theses illustrate the challenges, opportunities and benefits that building with nature presents. These cases highlight four important lessons for designing with nature in rural and urban landscapes.

First, considering the surrounding landscape as a starting point creates a deeper understanding of the situation at hand. This allows for better planning with the ecosystem and enhances the richness of its biodiversity once a project is delivered. Secondly, planning with nature creates the opportunity to let nature do some of the work. This can include water purification, drainage, and cooling. The third lesson is that designing with nature requires a long-term plan. Maintenance might be necessary, and the public may need to be patient to watch the ecosystem slowly flourish through the decades. Finally, creating a new kind of wilderness-imbued beauty to inspire public acceptance and to motivate stewardship is a promising method for establishing a successful long-term nature-inclusive design project. These and other lessons contribute to a field of design where incorporating nature is the status quo.

\section{KEYWORDS}

Landscape, nature inclusive design, landscape architecture, aesthetics, ecosystem services 


\section{Beautiful new landscapes for all that lives}

We live in increasing prosperity, while the distance from that which lives with us on earth is growing. Because of our actions, biodiversity is in decline, the climate is changing and we are creating new health risks for people and other beings (Franco, 2020). Of the 17 sustainable development goals defined by the United Nations (UN, 2015), seven are directly connected to the proper functioning of the global ecosystem. These are Zero hunger, Good Health and well-being, Clean water and sanitation, Sustainable cities and communities, Life below water, Climate action and Life on land. Ecosystem services (Millennium Ecosystem Assessment, 2005) are therefore expected to play a major role in reaching these goals.

The investment in people's nests and the work of landscape architects is mainly concentrated in urban areas. Many people, and with them, animals, leave the countryside to create their livelihood in urban areas (Ritchie and Roser, 2018). In the Netherlands, the cities and villages grow steadily (CBS 2019) while a lack of nature in our cities has a negative effect on our quality of life. Neighbourhoods experience heat stress, water problems, animal plagues and more. Furthermore, building projects often contribute to the decline of populations and ultimately push species to the brink of extinction. This blatant disregard for our fellow beings is not sustainable, and also unnecessary.

The earth can no longer be ignored as a powerful autonomous, living force in human affairs, says Bruno Latour in "Down to Earth" (Latour, 2018). We have to land on earth. It is a serious political factor today. Those who advance at the expense of the earth, he names them the 'globals', will have to reconsider their way of living. The locals, long seen as the losers, he says, are in fact the experts of how the earth works. The globals have to join hands with the locals, to find a new way of living. Building with nature makes us terrestrials and improves our relationship with the earth. Amongst recent building projects, some do involve nature as a serious partner. They are designed with a nature-inclusive approach, which proves promising for multiple reasons.

Instead of devouring space, the investment in human 'nests' unlocks living space for many living creatures other than humans. To achieve this, one can reshape the existing ecosystem into a new landscape with a sustainable equilibrium. Buildings are part of the ecosystem; they are rocks in the landscape, a welcome habitat for humans as well as for some bees, bats, and birds. They are placed to complete the ecosystem, much in the same way as a clump of trees is the finishing touch in a traditional English landscape park. Building with nature refines the practice of landscape architecture in a novel way, offering new opportunities for future development of rural and urban areas. 


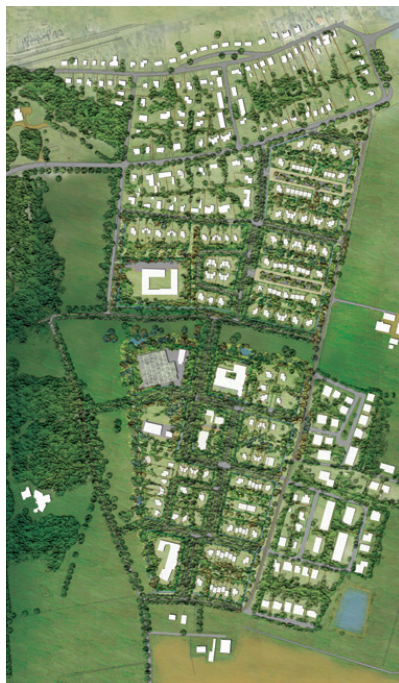

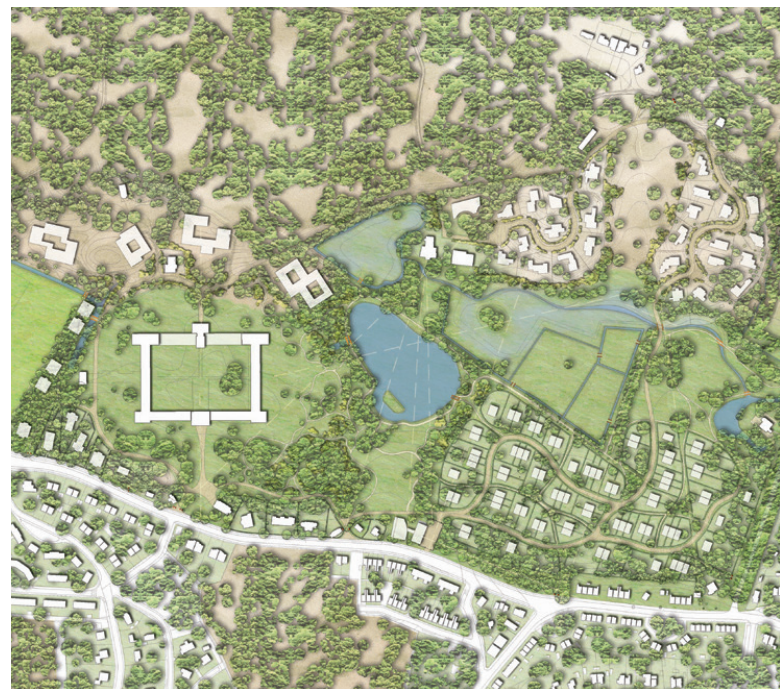

Figure 1. Achter 't Holthuis, Twello.

Figure 2. Park Brederode, Bloemendaal, 2003-2019.

While nature has always played an important role in aesthetics (Parsons, 2008) nature-inclusive design creates new kinds of aesthetics, in which wilderness and culture find a beautiful new balance.

The benefits of building with nature in spatial planning will be illustrated with four actualized DS landscape architects designs in the landscape of the Netherlands. These projects have put the principles of building with nature in practice, and some of the ecosystems have been growing further for several decades. These interventions serve a wider range of societal goals using the force of nature. To further illustrate this approach, we also look at two student's projects (Nieuwenhuijs, 2018; Van der Woude, 2019). They have the same nature-inclusive outlook as the projects by DS landscape architects. As purely theoretical projects, their content is not polished by reality, but this increases their illustrative power.

In four chapters and a discussion, a reflection is made on the landscape design practice of DS landscape architects. The design of an actualized landscape transformation is often related to a housing project. The aim of the transformation is to design a robust landscape where urbanisation can take place with the inclusion of nature. In retrospect, four important lessons are drawn for the design of nature in urban landscapes. These are: start with the landscape, let nature do the hard work, give the landscape time, and use beauty to inspire stewardship. 

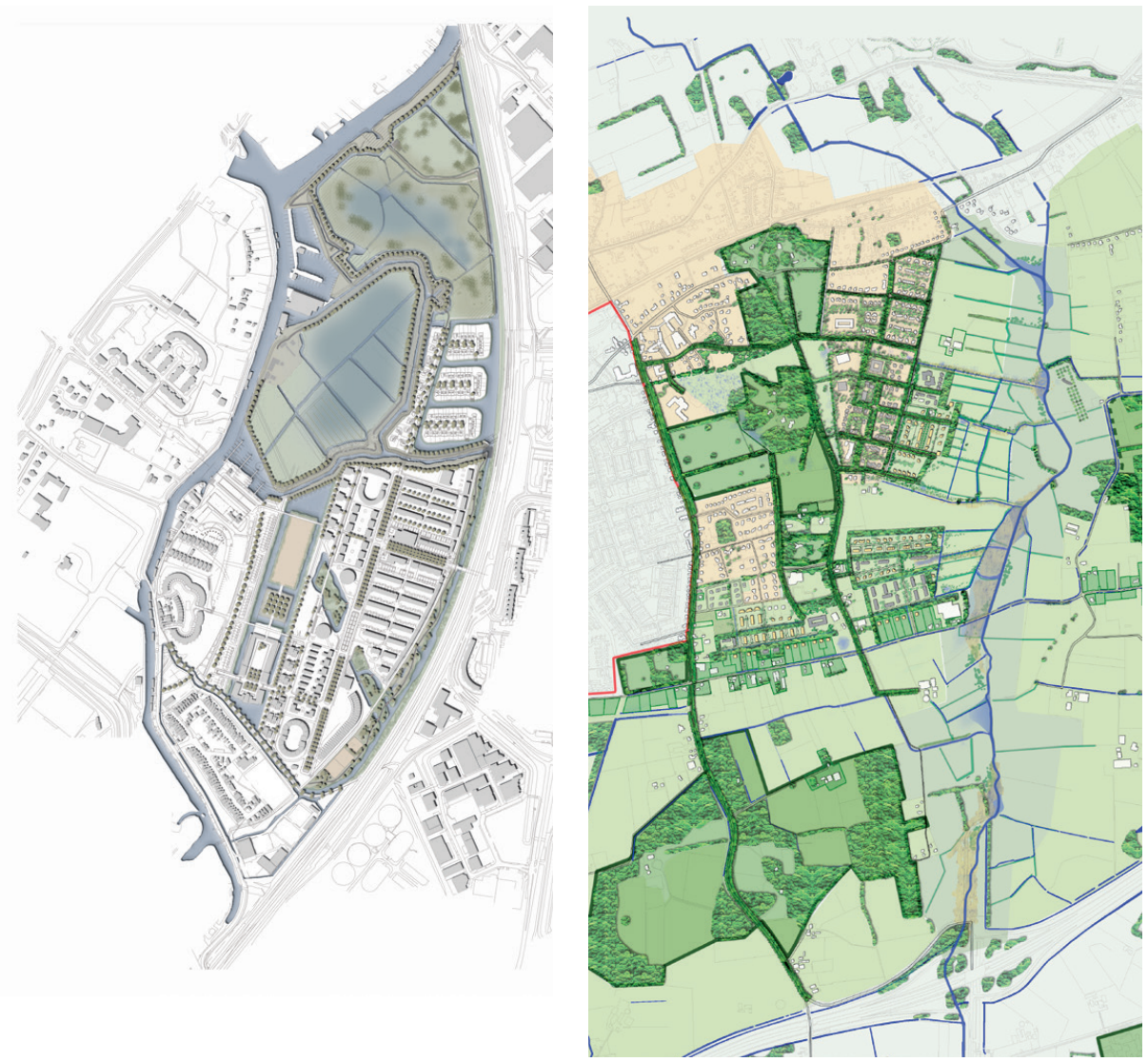

Figure 3. Landscape park Poelgeest, Oegstgeest, 1997 - 2005.

Figure 4. Fliertdal, Twello, 2014.

\section{Landscape first}

In situations where an existing landscape needs to undergo a transformation, DS landscape architects designs the landscape for all that lives with us. The result should be a rich landscape in addition to the fulfilment of the human program. To achieve this, DS designs the landscape first, to encourage the ecosystem towards a new, sustainable equilibrium. Afterwards, a housing program is rolled out. This is illustrated by two projects: Achter 't Holthuis (figure 1) and Park Brederode (figure 2).

In Achter ' $t$ Holthuis in Twello, a former sports complex is turned into a landscape of woodlands and open spaces, laced with lanes. The new function unlocks the possibility to create a vast new estate, encompassing two existing estates. The lanes and plant species tie into the existing ecosystem and the water network is linked with the Fliert brook valley (figure 4). This defragmentation makes the ecosystem more robust. 

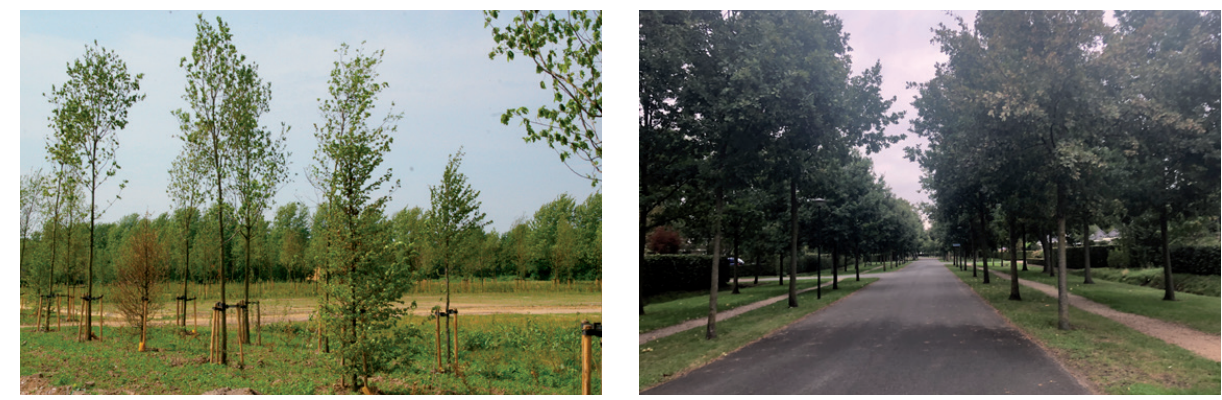

Figure 5. landscape built for the neighbourhood Achter 't Holthuis.

Figure 6. A stretched lane of Achter 't Holthuis.

The estate landscape is known for its bats. The straight, stretched lanes connect the mansions, providing beautiful sightlines towards the valley and the mansions. They also offer hunting space for the bats around the estates. Furthermore, these lanes benefit the drainage of the area, opening up the flow towards the open spaces. These spaces are local floodplains where the common spadefoot toad finds its breeding ground. The woodlands benefit a range of local species at all levels of the food web. The buildings are part of the ecosystem as well, they are rocks in the landscape, a welcome habitat for humans as well as for some bee, bat and bird species.

In Brederode Park the site has been inhabited by humans since the Middle Ages. For the last one hundred years it was a psychiatric hospital with well-maintained lawns and borders. The remnants of small estates, the traces of lanes, mixed with design elements of former parks were placed in a new landscape setting. The central area is transformed into a brook and inundation fields. The historic bleachfields are now meadows with wild grasses. The view of the dunes is opened up (figure 7).

The presence of good quality water is a vital part of the ecosystem. The common frog, amongst others, is given more space. In spring, the frogs $\mathrm{mi}^{-}$ grate from Kennemerduinen National Park to the site to breed in the ditches and ponds. The water for the brook is tapped from the dunes to fill a new brook and the inundation fields. The calcareous water also creates a unique habitat for endangered orchids.

On both sides of the valley the landscape absorbs human nests. On the west side, the landscape looks like an expansion of the local national park. The new sand hills are fixed with the endemic forest vegetation while local fauna arrives from the dunes, including deer, rabbits, finches and crickets. The villas are placed in vegetation, partially sunk into the terrain (figure 8).

The landscape on the east side has the spatial and natural qualities of a garden city. This area is ideal for hedgehogs, tits, and different species of butterflies. It reinterprets the park designed by the famous landscape architect, L.A. Springer. 

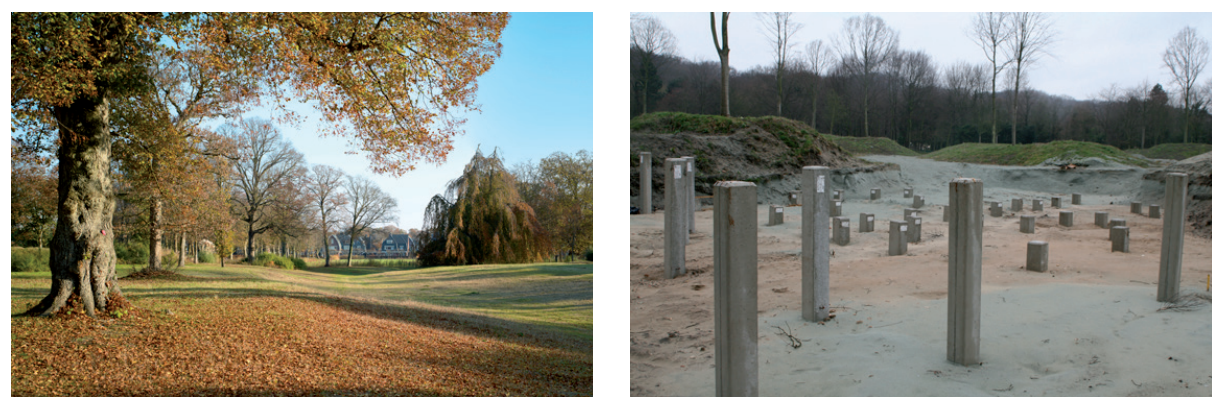

Figure 7. The new dune valley of Park Brederode (image by Walter Herfst).

Figure 8. The villas in Park Brederode partially sunken in the landscape.

The remaining tree groups, rich planting schemes, sight lines and path alignment are placed in a new landscape setting. More trees are planted and thick hedges line the fringe of the parcels (figure 9). In both projects, nature-inclusive design uses the surrounding landscape as a starting point to integrate human living spaces with a biodiverse ecosystem which has brought more endemic biodiversity to the site. The monotonous biotope of the sports fields was replaced by diverse, richer biotopes, such as a woodland, wild meadows and gardens that fit well into the ecosystem. The well-maintained hospital park biotope was changed into a fine grain mix of culture and nature. By studying the landscape to design and build with nature, the areas are now robust and accessible living environments for many species.

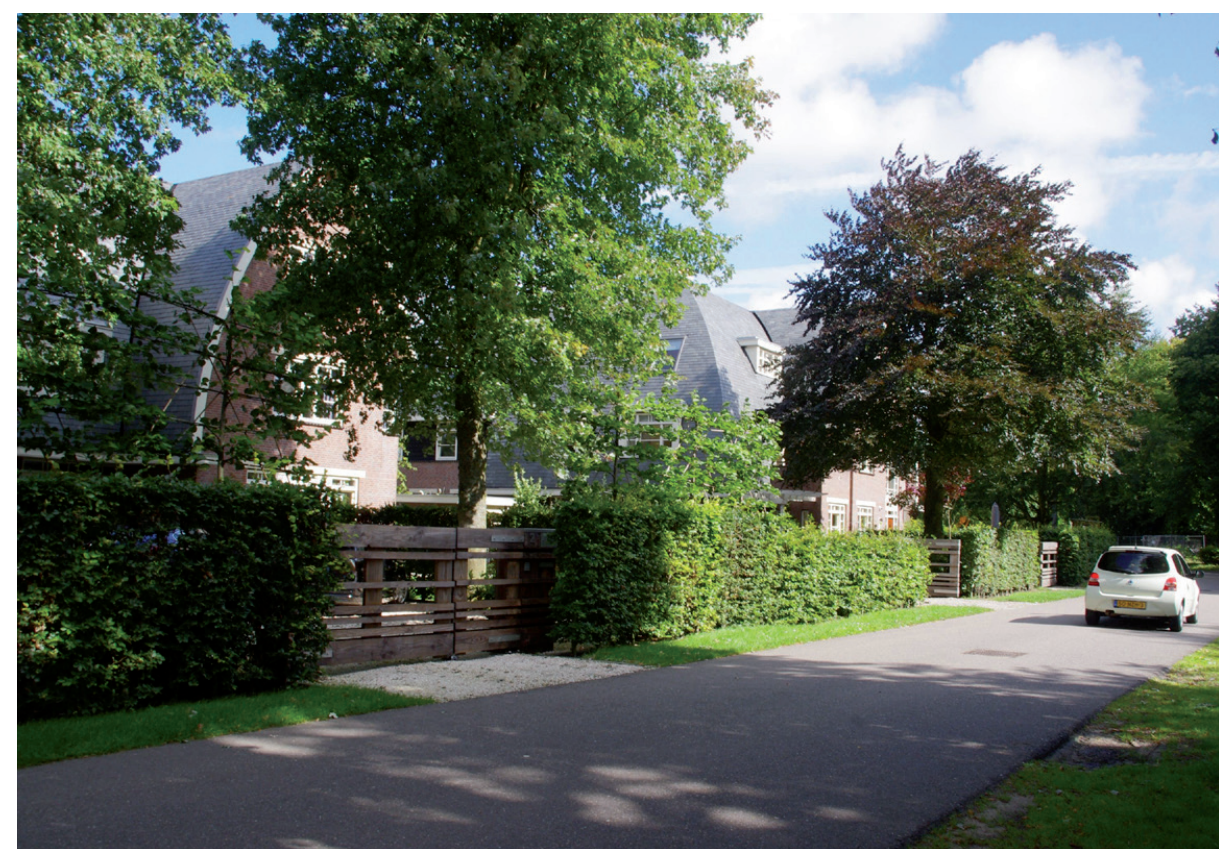

Figure 9. The neightbourhood Park Brederode on the east side. 


\section{Let nature do the work}

Quality of life remains a central development theme in the 21st century, and ecosystem services will play an indispensable role in providing it (Millennium Ecosystem Assessment, 2005). In the neighbourhoods described in this chapter, quality of life is improved due to the role that nature plays in the living environment especially when the landscape is made into a rich and robust ecosystem. A public space with lots of vegetation alleviates peak temperatures during heat waves. It also has the capacity to store and evaporate excess water during heavy rainfall and store moisture during periods of drought. The neighbourhood has cleaner air, stores $\mathrm{CO}_{2}$ and their inhabitants have reduced stress. Nature is at work for us.

The community living around the Fliertdal profits (in both a technical and cultural way) from this new, natural landscape of the Fliert brook. Dealing with the challenges of climate change, the water authority was in search of space for water retention, so the watercourse of the Fliert now includes space for the brook to meander. It allows for a rich ecosystem to develop on the site. The speed of the water flow is reduced, letting water infiltrate into the soil, creating a buffer for dry periods. The brook landscape, with an enlarged water surface, mitigates high surface temperatures during heat waves, while the abundant vegetation can absorb even more $\mathrm{CO} 2$ and produces more oxygen to breathe. The cultural contribution is that it allows people to be in nature while at and around their homes.

In Poelgeest the desire to clean local stormwater in a natural way motivated an approach of designing with nature. As a result, water drained from the urban area is diverted into the smallest polder. This polder has a labyrinth of ditches in a field of reeds. The clean water from this polder is pumped into the next polder for storage in order to gradually return it to the neighbourhood (figure 3). To enjoy nature at its best, the landscape can be entered by paths on the polder dykes. Here you also find birdwatchers using the dyke as a viewing platform. To step into the polder landscape boots are needed to take the small paths and planks bridge the ditches.

Anne Nieuwenhuijs (2018) uses the tidal flows of the Westerschelde in her conceptual project to filter the water and harvest toxic sludge. By means of small interventions, such as a dyke placed sensitively where the water flows, harvesting sites are designed for the removal of toxic sludge (figure 10). During high tide, the current in the estuary naturally deposits the toxic sludge in the basin. Low tide is used to harvest the sludge out of the Westerschelde, releasing cleaner water back into the sea. Toxic sludge is then compressed into harmless rocks. This makes it possible to turn a local nature-abusing substance into material to support the local ecology. The building blocks are used in small projects for landscape development along the Westerschelde. 


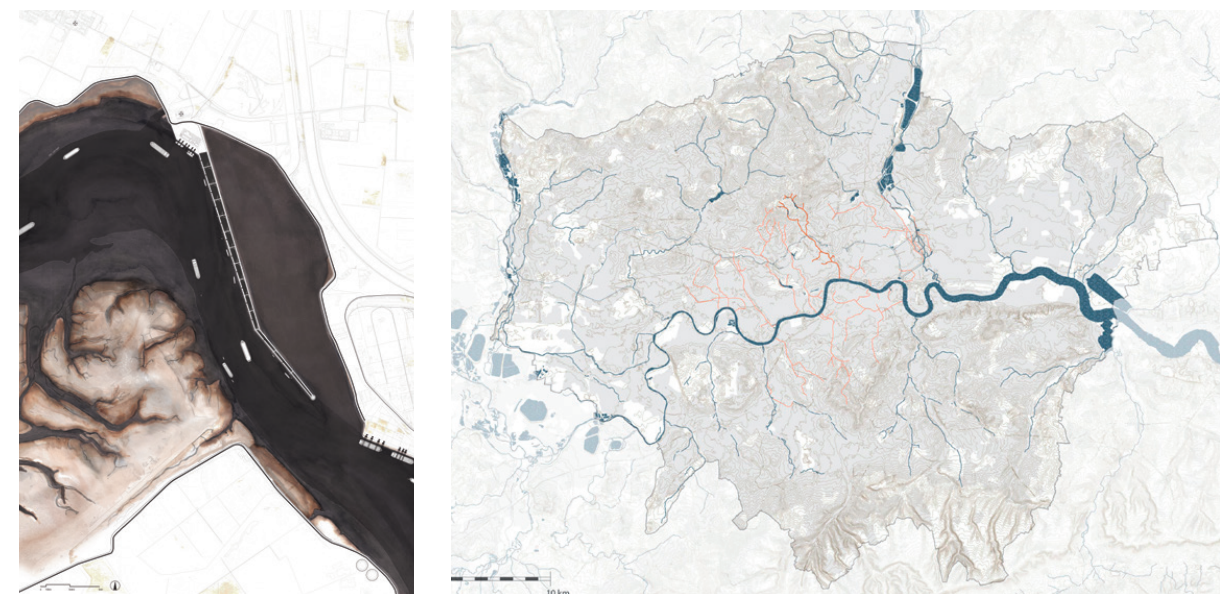

Figure 10. A dyke placed on the waterflow in the Westerschelde.

Figure 11. Tight network of natural brooks under London.

With these blocks, a landscape can be made, offering new opportunities for ecology, spatial quality and landscape dynamics.

The employment of natural processes, both technically and aesthetically, is not limited to rural areas. With nature's help, Charlotte van der Woude (2019) projects a future for the city centre of London (figure 11). This city is built on a tight network of natural brooks, currently in use as sewers. In this design project, nature ventilates the densely-built city by opening up windows to the original waterways of London. The openings work as an air conditioner, cooling the city on a hot summer day. The openings absorb rainwater in the event of big storms. They also restore access to the landscape below the city, where previously absent life forms thrive quietly. By letting nature back in, the quality of life of the inhabitants is improved with ecosystem services. These interventions provide excellent recreational sites, combined with climate adaptive solutions. Unrealised and realised, these projects propose a new symbiosis between nature and occupation, delivering unexpected and beautiful landscapes.

\section{Cultivation in time}

When building with nature, it takes time for ecosystems to develop into a natural, resilient ecosystem. The desired population of species needs a chance to establish and determine their natural interactions with other species in motion. It requires patience to let an ecosystem grow in a neighbourhood. Residents need to suppress their inclination to interfere prematurely. To increase the overall biodiversity in time we need rules and policies, good management, and education for inhabitants. 

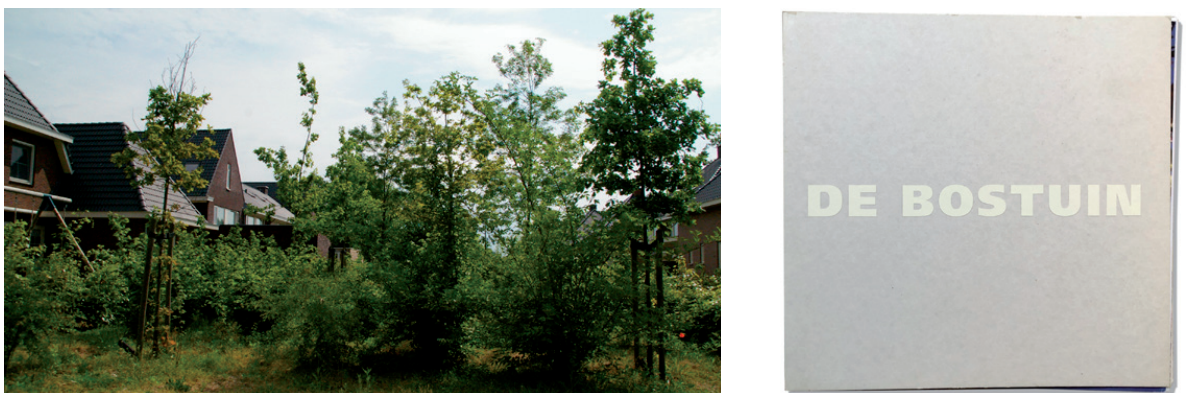

Figure 12. Woodlands in the neighbourhood Achter 't Holthuis.

Figure 13. The Woodland garden manual, DS 2005

In the neighbourhood Achter 't Holthuis, the houses stand in woodlands which are part of the public space (figure 12). Maintenance activities are organised by the communal gardening service as they have specific local knowledge of their own landscape. The woodlands cast a shadow over the gardens, something Dutch residents usually complain about. It is very common and, in such cases, inhabitants ask the community to cut down the trees. The "Woodland garden manual" was made to increase respect for the surrounding woodland and thus the tolerance to let it grow. Providing many examples of compatible plant and animal species, it also inspires newcomers to adapt their gardens to the surrounding ecosystem (figure 13). It lists beautiful, indigenous shade-loving plants that can be bought at the local nurseries and garden centres. To envision the look of a woodland garden, show gardens were made together with students from the nearby school of horticulture. The stewardship for the woodlands is an ongoing effort and it is crucial to give the landscape of woodlands, open spaces and lanes time to develop into a sustainable ecosystem.

The Fliertdal is owned by nature foundations and private landowners so the success of the development of a sustainable ecosystem and beautiful valley depends on their cooperation. The Fliertdal toolbox is provided to guide them and consists of 20 sheets of paper that each depicts a landscape element for the valley. The appearance, the planting plan and the maintenance of each element are described on the sheet (figure 14). The landowners can apply for subsidies for the elements from the toolbox. However, if they decide to plant conifers, they will not get financial support. The toolbox system increases the chance that the landscape will evolve into the desired type of ecosystem.

In Poelgeest, the landscape park was sold to Het Zuid-Hollands Landschap, a non-profit firm specialised in the management of small nature areas. With their management, the long-term development of nature is in good hands. They organise working events for volunteers in the landscape to increase stewardship. Many inhabitants join these days to stay in touch with the unique natural elements found in their living environment. 


\section{Vlechtheggen}

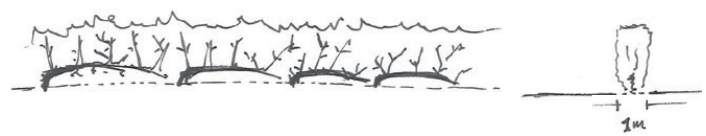

Heggen geven het dal van de Fliert een ander meer kleinschalig karakter. Heggen worden zo veel mogelijk aangeplant op plaatsen waar ze vroeger ook hebben gestaan, meestal op de vochtigere delen van het dal. De vlechtheg is een speciaal soort heg die veel langs de Fliert voorkwam. Bij de vlechtheg wordt het te snoeien hout niet afgeknipt of gezaagd maar ingehakt. De half doormidden gehakte takken worden omgebogen en vervlochten met andere takken en stammen. Vlechtheggen zijn lage, tot maximaal 2 meter hoge randbeplanting bestaande uit een gering (1 tot 5) aantal soorten, inheemse struiken. Vlechtheggen worden jaarlijks gesnoeid en gevlochten.

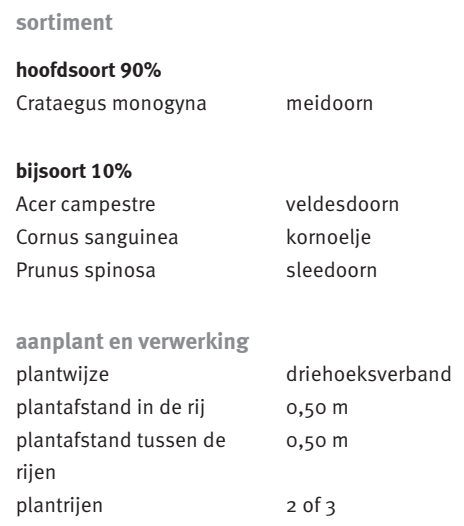

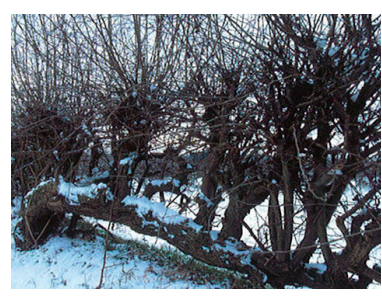

eerste vervlechting na 6 tot 8 jaar na aanplant door stammen half in te hakken en om te buigen

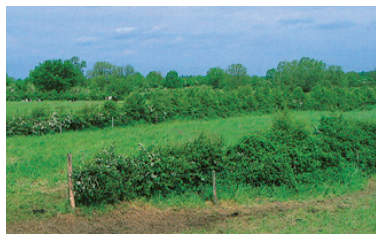

beheer vanaf 6 tot 8 jaar na aanplant uur / jaar tijdstip uitvoering

uitlopers half inhakken en opnieuw invlechten

$1 \mathrm{x} /$ jaar $100 \% \quad 20 / 100 \mathrm{~m} 1 \quad$ november - februari

overstaanders handhaven ongeveer 1 per 10om 1

$1 \times /$ jaar $100 \% \quad 0,5 / 100 \mathrm{~m} 1 \quad$ juni - september

onderbegroeiing selectief maaien

natuur

natuurdoeltype struweel/mantel/zoombegroeing

doelsoorten

zoogdieren
vogels
reptielen
amfibieën

boommarter, das, franjestaart (vleermuis)

blauwe kiekendief, groene specht, steenuil, wielewaal

hazelworm, ringslang

kamsalamander, knoflookpad

\section{subsidie}

aanleg per $100 \mathrm{~m} 1$

beheer per $100 \mathrm{~m} 1$

Figure 14. Sheet from the Toolbox Fliertdal.

During the opening of the park in 2011, expert excursions were organised, and 50 fishing nets were dealt out for the local children to play with in the landscape (figure 15).

The conditions for a rich, biodiverse ecosystem that was established in Brederode Park are expected to develop together with the new inhabitants. We educated the developers, architects, and brokers to respect the aim of the landscape design and to convey the ambition for nature to the new owners. 

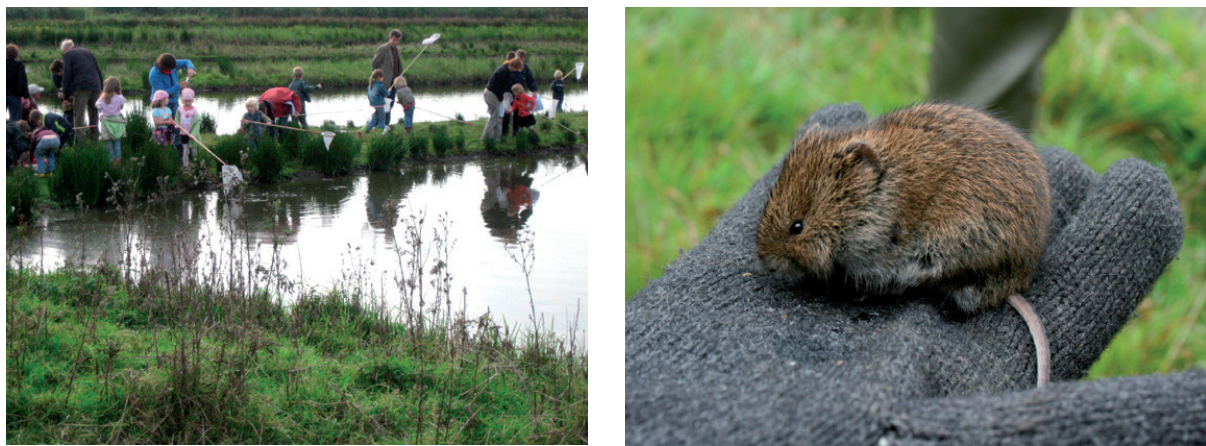

Figure 15. Fishing nets for the local children at the opening of Poelgeest landscape park.

Figure 16. The root vole, protected species in Poelgeest (image by Marte Holten Jørgensen).

This legislation will help the landscape to develop in time. A part of Brederode Park is designated as wilderness. For gardens in the dunes, a special regulation is applied, aiming to create conditions for wild animals to live there. It is called 'NLT- natuurlandschappelijke tuin'.

Finally, a maintenance plan is written to gradually reach the goals for nature and the landscape. The advice to choose in Brederode Park for an experienced nature organisation like 'Het Zuid-Hollands landschap' was not followed. The community did choose an organisation employing people with disabilities to do the work, because of their cost-efficiency. These people are not particularly knowledgeable in the environmental realm. The missed opportunity here, is the fact that untrained workers cannot increase stewardship by sharing their expertise with the inhabitants while working on site.

Another way to support the cultivation of the landscape in time is through alliances with other organisations, such as a water authority. This is the case for Fliertdal, Poelgeest, London and the Westerschelde. Flora and fauna legislation sometimes demands relocation or protection of species habitat in development sites (Brederode Park, Achter 't Holthuis, Poelgeest). Such legislation can be an important driving force in the establishment of new ecosystems (figure 16).

The average budget for green maintenance in public space is extremely low. Nature organisations often have to work with underqualified volunteers while horticultural firms work with people with disabilities to keep costs low. Maintenance professionals tend to maintain the natural elements that already exist, but have limited resources to expand and improve that which is designed by the landscape architect. It is therefore often wise to design landscapes in which the ecosystem takes care of itself as much as possible and allow time run its course. 

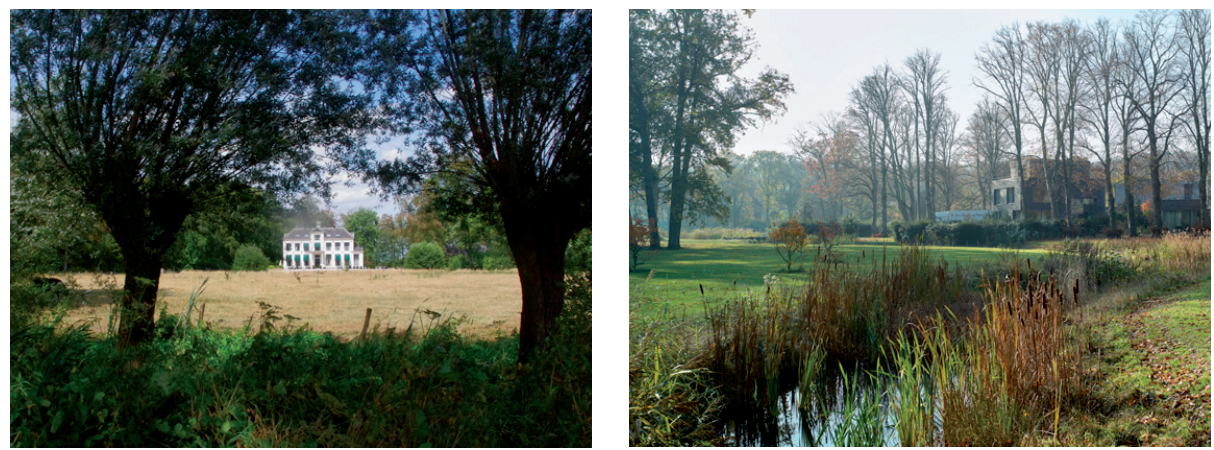

Figure 17. View on estate 'Hunderen' in Twello.

Figure 18. The new brook in Park Brederode (image by Walter Herfst).

\section{Beauty for stewardship}

How can we reach the next level in planning? It is through winning hearts that we win minds. While nature is an important inspiration for aesthetics (Parsons, 2008), people generally are more engaged with wilderness that is conformed to the human scale and shape (Gobster et al. 2007). The landscape architect is trained to improve the aesthetics in the landscape on a human scale. In nature-inclusive designs, it is the ability to make beauty with wilderness that helps to create acceptance of nature in people's living environments. To create an aesthetic nature-inclusive landscape, DS landscape architects considers three aspects of beauty in every project. These are the composition, the cultural beauty, and the extent to which a landscape is expected to create beauty in experiences. Increasing the beauty of a landscape inspires better stewardship and is an underestimated tool for increasing biodiversity.

In Achter 't Holthuis, it is the historical estate landscape that seduces. The composition of mansions, lanes, woodlands, and fields offers the passengers memorable visits (figure 17). Walking in Brederode Park, along the brook in the buzzing fields, with the high dunes on the horizon, and the historic remnants around, is like experiencing sublime beauty (figure 18). The composition of landscapes works to create a sense of beauty and in the best case, belonging.

Beauty is also a goal in the toolbox strategy in the Fliertdal. One of the subsidised elements in the toolbox is the hawthorn hedge. If many residents plant this species, the synchronous white blossoming of a large number of these bushes in early spring will be an attraction for both hikers and residents.

The beauty of Poelgeest lies in its concept. It fulfils its new job simply with the planted reed. In the reedscape, the water is purified while the 'Waterwheel' art piece gently rotates. The habitat of the protected tundra vole is 
saved and the landscape park is now a hotspot for birds and bird watchers. A colony of spoonbills is the finishing touch to make this area an attractive place to be and to care for.

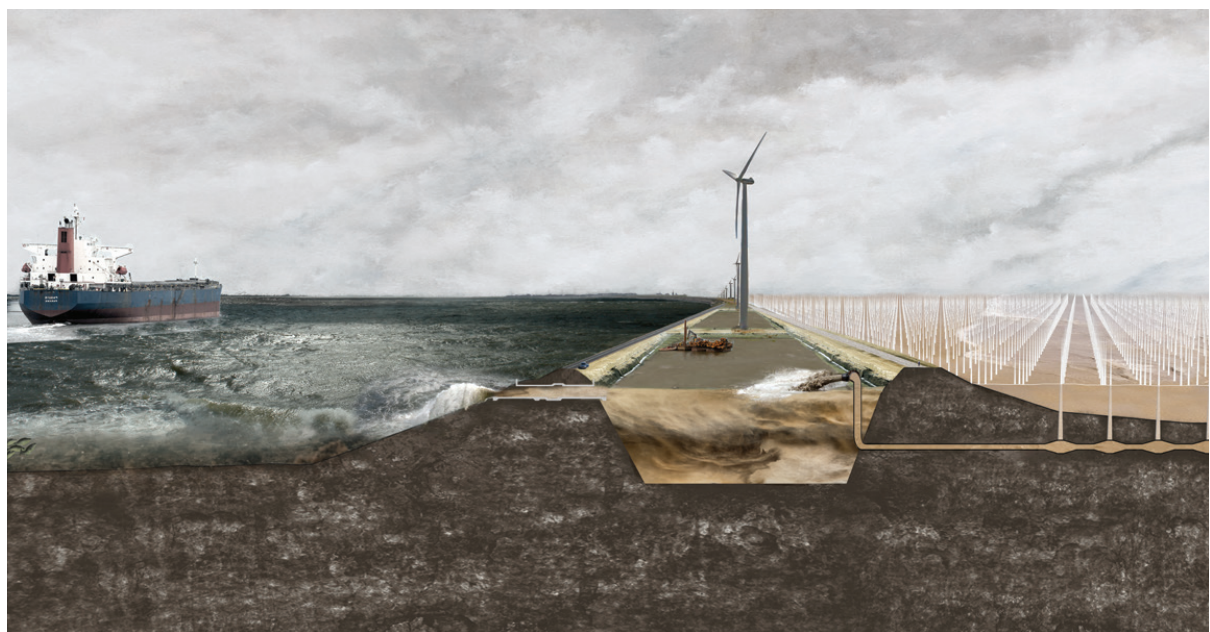

Figure 19. The working of the needle landscape expressed in crossection, Westerschelde.

In Anne's design, an eerie needle landscape of 50oha is envisioned (Nieuwenhuijs, 2018). The tall pointy pillars have a perforated base. Through it, they suck up the contaminated sludge (figure 19). That is then pumped into a nearby sludge depot. The pumping landscape is a sublime minimalistic machine providing its own kind of beauty.

In the London project (Van der Woude, 2019), six interventions are proposed throughout the underground landscape of brooks. This will create new microclimates for new biotopes in the public space. The sites with windows to the underworld infuse the public spaces in London with a new, unexpected kind of beauty, provided by the mysterious, Victorian, brick sewage network. It is designed to invoke a unique aesthetical experience.

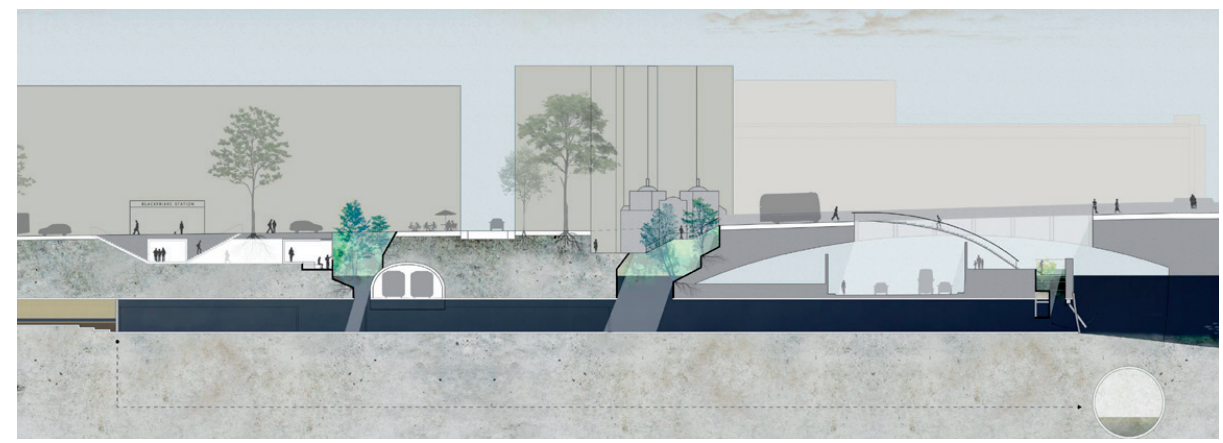

Figure 20. Windows above waterways subjected to ebb and flow, London. 
One of these windows is particularly interesting. The Thames is a tidal estuary, and Charlotte proposes to open one of the windows above waterways subject to ebb and flow (figure 20). The pathways are drawn on a height that allows visitors to touch the water during high tide.

To design for a beautiful, nature-inclusive landscape inspires greater acceptance of a project. Combining wild, natural elements with cultural preferences creates a new aesthetic that is appreciated by the public. DS landscape architects therefore always use it as an important guiding principle for building with nature.

\section{Towards a broader practice of designing with nature}

Nature-inclusive landscape design, as a conscious way of employing ecosystem services in urban settings, potentially offers an important contribution to reaching the millennium development goals.

From the perspective of the designer at DS landscape architects, four main principles provide important lessons to the field of building and designing with nature. Together, they illustrate that nature-inclusive design may require some extra work and thoughtfulness, particularly in the planning phase, but it also yields benefits that could well outweigh the investment. These cases do not bring forth a detailed cost-benefit analysis, but they certainly do draw the attention to values and yields that have not always been included in the equation. The quality of life of our human and non-human companions being a prominent example, the provision of ecosystem services another.

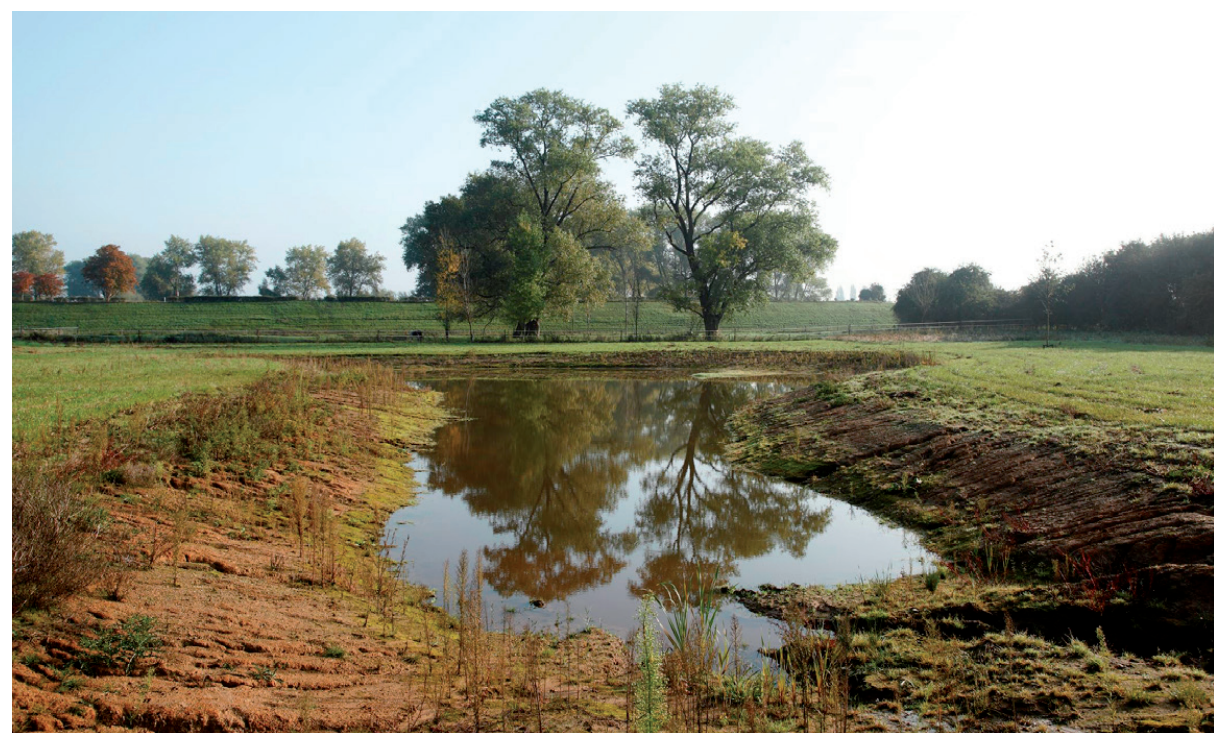

Figure 21. Building the new landscape of the Fliertdal (image by M. Hirschler). 

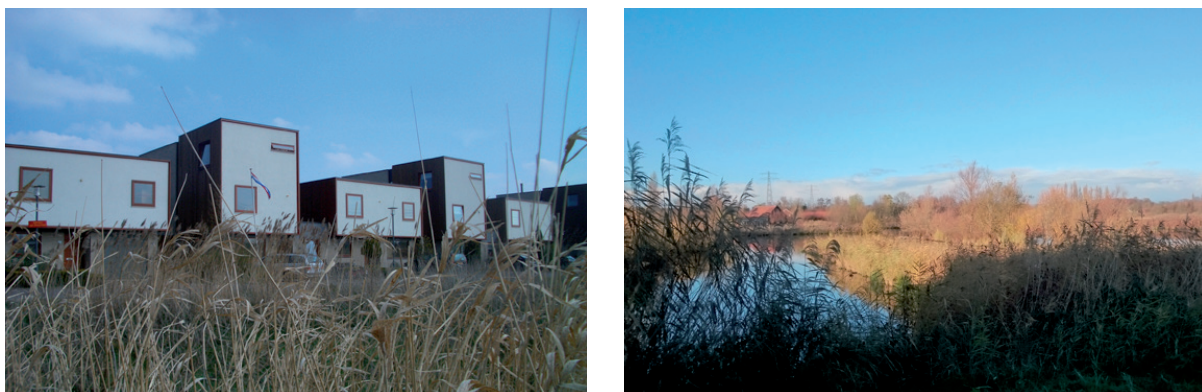

Figure 22. Nature nearby, Poelgeest.

Figure 23. The reed field in the smallest polder of Poelgeest.

The first principle, landscape first, illustrates that by paying careful attention to the landscape and its surrounding ecosystem, nature-inclusive designers can arrive at innovative solutions that work with, rather than against, nature. This is what Bruno Latour refers to when expressing that we can no longer design our 'nests' without incorporating the habitats of what lives with us. We are part of the earth and expressing that in our design work is a viable option. Biodiversity can and will increase if we remain sensitive to it.

In a time where lives accelerate and maintaining the status quo requires increasing effort, it is all the more comforting to know that we can design in such a way that nature takes over some of the work. Ecosystem services are not just a benefit we receive from our natural environments, they are concepts that can be planned and designed for (figure 22). Why build expensive high-tech water-cleaning filters if something as simple as a bed of reeds can achieve a similar effect, such as in Poelgeest? Why create intricate drainage systems to pump water up, if you can let it flow down and create a habitat for spadefoot toads, as was done in the Fliertdal? Letting nature do the work means looking at a site for just a little longer, to find the opportunities that ecosystems have in store for us.

Working with nature - not in spite of nature - requires a certain amount of patience, long-term commitment and maintenance. Results will not always appear within a year or even a decade. It requires cultivation over time, the third principle, to allow the development of an ecosystem. That applies to all actors, meaning that education and awareness-raising may be needed for residents, as was done in Achter ' $t$ Holthuis and Fliertdal. That requires expertise and a common understanding, which, as in the case of Brederode Park, will not always be funded the way it was planned for by the designers. While a collaborative effort between the stakeholders may be reached with incentives, maintenance laws and policies can be required to guarantee continuity, as was done with designated wilderness areas in Poelgeest. In sum, it may be wise to plan for a situation where a resilient ecosystem maintains itself as much as possible. 

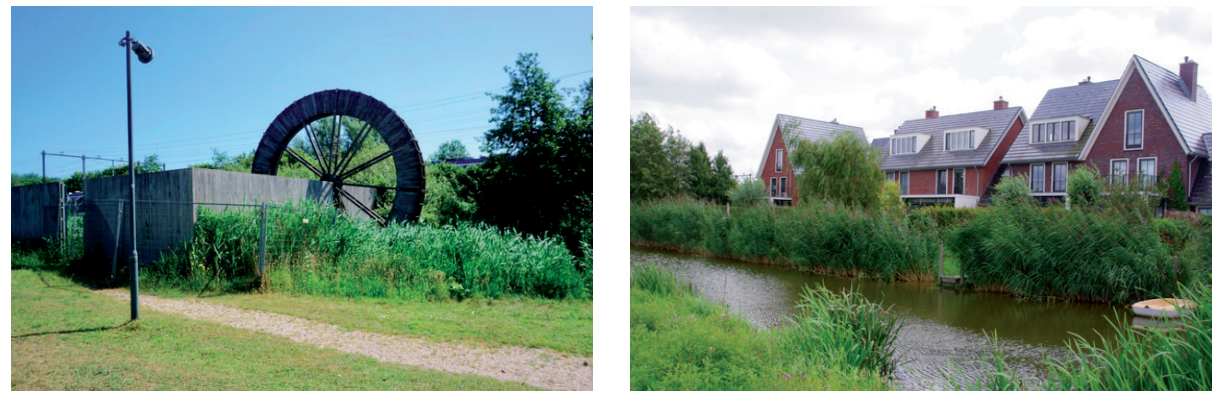

Figure 24. The waterwheel bringing the clean water back to the neighbourhood.

Figure 25. Nature in the neighbourhood Poelgeest.

Aesthetics and beauty should be a vital part of any nature-inclusive design, increasing biodiversity and building with nature. Nature-inclusive design is a new way of controlling wilderness and perceptively working with wild biodiversity creates a new kind of aesthetics. In a situation where stewardship over the land is required, such as drawing in volunteers for maintenance activities or to create political will for conservation of an area or execution of an idea, the element of beauty is often highly underestimated. DS landscape architects sees this quest as the next challenge for building with nature: to develop a new landscape architecture language that is able to connect the technique of building with nature with new aesthetic experiences for all beings involved.

Robust landscapes with rich and diverse ecosystems protect species, regulate and clean water, provide fresh air, reduce temperature extremes, stabilize water tables, and are generally healthier. Despite increasing environmental risks, let us be hopeful for the future of neighbourhoods for humans, plants and animals. Wild nature is an increasingly accepted part of our living environment. Nature is no longer to be seen as a threat or as something dirty, but more and more as a partner for confronting the changes ahead. It can be functional and beautiful at the same time. The provided examples of nature-inclusive design demonstrate that these qualities can and should be brought into reality.

\section{Acknowledgements}

The projects of DS landscape architects were carried out in close collaboration with Bruno Doedens, who was part of the organisation at the time. The author would like to thank him for his indispensible work in these projects. Editor and English translator Gilles Havik

\section{Author disclosure statement}

The authors disclose that no competing financial interests exist for the publication of this article. 
Centraal Bureau voor de Statistiek. (2020, December 3). Wat is verstedelijking? https://www.cbs.nl/nl-nl/ dossier/dossier-verstedelijking/hoofdcategorieen/wat-is-verstedelijking-

Franco, E. G. (2020). The Global Risks Report 2020. World Economic Forum. https://www.weforum.org/ reports/the-global-risks-report-2020

Gobster, P. H., Nassauer, J. I., Daniel, T. C., \& Fry, G. (2007). The shared landscape: what does aesthetics have to do with ecology?. Landscape ecology, 22(7), 959-972. https://doi.org/10.1007/s10980-0079110-x

Latour, B. (2018). Down to earth: Politics in the new climatic regime. John Wiley \& Sons.

Millennium Ecosystem Assessment. (2005). Ecosystems and Human Well-being: Synthesis. Island Press. http://www.millenniumassessment.org/documents/document.356.aspx.pdf

Nieuwenhuijs, A. (2018). Vloeibaar land. Amsterdamse Hogeschool Voor de Kunsten (AHK). https://www. ahk.nl/eindwerkprijs/eindwerkprijs-2018/master/vloeibaar-land/

Parsons, G. (2008). Aesthetics and nature. Bloomsbury Publishing.

Ritchie, H., \& Roser, M. (2018, June 13). Urbanization. Our World in Data. https://ourworldindata.org/ urbanization

United Nations. (2015). Take Action for the Sustainable Development Goals. United Nations Sustainable Development. https://www.un.org/sustainabledevelopment/sustainable-development-goals/

van der Woude, C. (2019). NATURE IS UNDER YOUR FEET Discovering London's underground landscape as a potential new nature. Academy of Architecture. https://www.bouwkunst.ahk.nl/en/graduates/2019/ student/charlotte-van-der-woude/ 